\title{
海马-前额叶神经回路与工作记忆
}

\author{
王功伍 ${ }^{1}$, 蔡景霞 ${ }^{2, *}$ \\ (1. 云南师范大学 生命科学学院 云南 昆明 $650092 ; 2$. 中国科学院昆明动物研究所 脑与行为实验室 云南 昆明 650223)
}

摘要: 学习和记忆是神经科学研究的热点。已证实大脑中的海马、前额叶和海马-前额叶回路均参与工作记 忆功能。该文对海马-前额叶回路的解剖和生理特性以及海马、前额叶和海马-前额叶回路在工作记忆中的作用的 研究进展做一概述。

关键词: 海马; 前额叶; 海马-前额叶回路; 工作记忆

中图分类号: Q189; Q427 文献标识码: A 文章编号: 0254-5853-(2010)01-0050-07

\section{Hippocampal-Prefrontal Cortical Circuit and Working Memory}

\author{
WANG Gong-Wu ${ }^{1}$, CAI Jing-Xia ${ }^{2, *}$ \\ (1. School of Life Sciences, Yunnan Normal University, Kunming 650092, China; 2. Laboratory of Brain and Behavior, \\ Kunming Institute of Zoology, the Chinese Academy of Sciences, Kunming $\quad 650223$, China)
}

\begin{abstract}
The study on learning and memory is one of the striking subjects in neuroscience today. In the cerebral cortex, it is has been proved that, the hippocampus, the prefrontal cortex and the hippocampal-prefrontal cortical circuit are important to working memory. In this paper, we review findings of the anatomical and electrophysiological characteristics of the hippocampal-prefrontal cortical circuit and the roles of these three structures in working memory.
\end{abstract}

Key words: Hippocampus; Prefrontal cortex; Hippocampal-prefrontal cortical circuit; Working memory

在本文中, 海马(hippocampus)指的是海马结构 (hippocampal formation), 包括齿状回 (dentate gyrus)、阿蒙氏角(Ammon's horn)和下托(subiculum) 三部分。阿蒙氏角可以进一步划分为 CA1、CA2 和 CA3 三个主要的亚区。前额叶(prefrontal cortex)是 位于大脑皮层最前方的部分, 在额叶运动区和辅助 运动区之前。海马和前额叶与学习和记忆等脑高级 认知功能密切相关。记忆包含获得 (即学习) 、巩 固和提取信息的三个过程。记忆的重要意义在于它 可使人和动物能利用外部世界的表象来指导行为 反应, 使其在进化竞争中处于非常有利的地位。工 作记忆(working memory)是一种特殊的短时记忆, 具有短时存储、实时刷新和容量有限的特点, 是动 物计划和组织行为、语言、思维和决策等高级认知
功能的基础(Baddeley，2003)。可用延缓反应任务 (delayed response task)、交互延缓任务 (delayed alternation task)等延缓任务测试人或动物的工作记 忆能力(Oscar-Berman et al, 1991; Xu \& Cai, 2009)。 前额叶是工作记忆的关键脑区(Funahashi et al, 1989; Goldman-Rakic, 1987), 海马也在工作记忆中起重要 作用(Olton et al, 1979)。解剖学研究已经证明, 海马 和前额叶之间存在单突触联系, 即海马一前额叶回 路, 但人们对其功能不完全明了。人们推测该回路 可能对海马和前额叶这两个重要的脑区的信息起 协调和沟通作用, 并极可能参与记忆等认知功能。 近 10 年来, 对海马一前额叶回路的认知功能已有较 多报道。本文将简要综述海马一前额叶回路的解剖 学和电生理学特性, 及海马、前额叶和海马-前额

收稿日期：2009-12-25; 接受日期：2010-01-04

基金项目：云南省社会发展科技计划应用基础研究项目（2007C051M); 中国科学院“西部之光”人才培养计划项目(2008); 973 计划项目 (G1999054000); 国家自然科学基金项目（30070251）

*通讯作者（Corresponding author), E-mail: caijx@mail.kiz.ac.cn

第一作者（First author）简介：王功伍（1975-), 博士，副教授，主要从事学习和记忆相关的神经生物学研究，E-mail: waov@tom.com 
叶回路在工作记忆中的作用的研究进展。

\section{1 海马-前额叶回路的解剖学性质}

解剖学研究表明, 从海马到前额叶的神经投 射, 具有单突触、单向和同侧投射的特点(Laroche et al, 2000; Thierry et al, 2000)。 Rosene \& Van Hoesen(1977)首先报道恒河猴的下托到前额叶内侧 部存在直接的神经投射。Goldman-Rakic et al (1984) 则证明恒河猴的下托到前额叶背外侧部存在单向 投射。Barbas \& Blatt(1995)的研究表明, 恒河猴的 海马到前额叶的投射呈地形图样分布, 海马到前额 叶的腹内侧部的投射最密集, 其次是睈额部, 只有 很少的纤维投射到外侧前额叶; 海马投射到前额叶 的神经元胞体在海马中的分布也呈地形图样分布, 主要分布在 CA1 区的嘴侧 (腹侧) 以及下托的尾侧 (背侧)。Cavada et al(2000)在一篇关于猴眀额叶解 剖联系的综述中对猴海马与前额叶眀额部之间回 路的解剖学特点有详细的描述。 Irle \& Markowitsch(1982)及 Cavada et al (1983)证明猫的海 马下托也有纤维投射至前额叶内侧和腹侧部。

Swanson (1981)证实大鼠上也存在从海马投射到内 侧前额叶下边缘皮层(infralimbic cortex)的神经纤 维, 其主要来自腹侧的 CA1 区, 下托也有密集的纤 维投射到下边缘皮层。Jay et al (1989)发现大鼠腹侧 海马 CA1 区和下托有纤维选择性的投射到前边缘 皮层 (prelimbic cortex) 和内侧眀额皮层。Verwer et al (1997)的研究表明, 大鼠海马 CA1 区和下托有小 部分雉体细胞的神经纤维选择性地投射到外侧前 额叶, 其中半数细胞同时有分支投射到内侧前额 叶。Croxson et al (2005)采用磁共振弥散加权成像 (diffusion weighted imaging, DWI)技术证明, 人脑中 存在与猴脑类似的海马至前额叶的神经投射。免疫 细胞学研究则进一步表明, 前额叶中来自海马的传 入纤维除了与前额叶雉体细胞形成单突触连接外, 还与 GABA 能中间神经元形成单突触连接, 这种连 接方式可将前额叶锥体细胞的兴奋状态控制在一 定的水平, 不至于兴奋过度(Gabbott et al, 2002)。最 近一项采用免疫苂光技术进行束路追踪的研究, 明 确了从腹侧海马发出的神经纤维主要沿着海马伞穹隆经前联合前方进入前额叶, 终止于前边缘皮层 区和下边缘皮层等处(Parent et al, 2009)。总之, 海 马一前额叶投射主要起自腹侧海马的下托和 CA1 亚 区, 终止于前额叶的内侧、眀额侧和外侧部分。
一般认为, 前额叶到海马不存在直接投射。前 额叶信息主要通过扣带回、旁海马回、内嗅皮层等 间接传递到海马 (Fuster, 1997; Goldman-Rakic, 1984)。丘脑连接核(nucleus reunions of thalamus)是 丘脑向海马投射的主要核团, 解剖学研究表明, 大 鼠连接核接收内侧前额叶的所有 4 个亚区的神经纤 维的投射, 可能是把前额叶的信息传递至海马的一 个重要核团(Vertes, 2002, Vertes et al, 2007)。也有报 道说前额叶有神经纤维直接投射到海马, 只不过数 量非常稀少(Leichnetz \& Astruc, 1975; Hurley et al, 1991; Sesack et al, 1989)。海马一前额叶回路是海马 和前额叶之间存在功能联系的解剖学基础（图 1)。

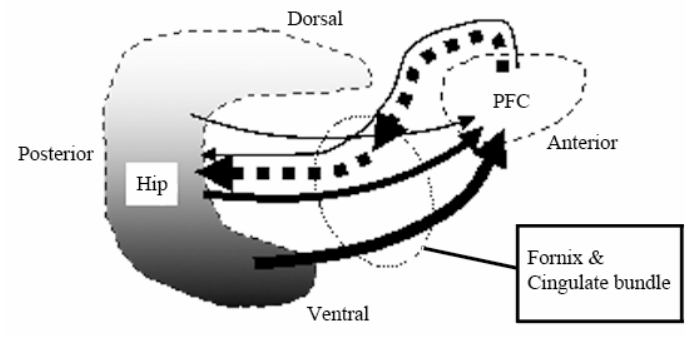

图 1 海马-前额叶回路示意图

Fig. 1 The sketch map of the hippocampal-prefrontal cortical circuits

灰度 (grades of gray): 海马中发出神经纤维到前额叶的神经元胞体的密 度(the distributional intensity of the cell bodies of the projection neurons in the hippocampus); 实线箭头(arrows with solid line): 直接投射(direct projection); 虚线箭头 (arrows with broken line): 间接投射(indirect projection); 箭头线的粗细(thickness of the line of the arrows): 投射纤维 的密度(intensity of the projection); Hip: 海马(hippocampus); PFC: 前 额叶(prefrontal cortex)。

\section{2 海马-前额叶回路的电生理学性质}

早年的研究表明, 海马一前额叶突触与很多部 位的突触类似, 具有可塑性。电刺激大鼠腹侧海马 的下托或 CA1 亚区, 可以在内侧前额叶记录到兴奋 性突触后电位, 并且可以在前额叶诱导出长时程增 强 (long-term potentiation, LTP) 和长时程抑制 (long-term depression, LTD; Burette et al, 1997; Jay et al, 1995, 1996; Laroche et al, 1990; Takita et al, 1999; Zhang \& Cai, 2008)。Laroche et al（2000)认为在海 马一前额叶突触可诱导出 LTP 说明海马一前额叶回 路可能参与记忆巩固过程。Dégenètais et al (2003) 发现, 对海马施以单脉冲刺激可在前额叶雉体细胞 记录到早期的兴奋性突触后电位和稍晚的抑制性 突触后电位; 以特定的参数刺激海马, 不仅可在前 额叶诱导出 LTP 和 LTD 等长时程突触可塑性现象, 
还可以诱导出短时程突触可塑性现象。而 Izaki et al (2003) 则发现, 用高频刺激海马在前额叶诱导出 LTP 后再用低频刺激可迅速诱导出 LTD, 反之亦 然, 说明海马一前额叶突触具有双向灵活性。以上 电生理研究结果支持解剖学研究中的发现, 表明海 马和前额叶之间存在神经纤维投射, 海马一前额叶 回路具备参与学习和记忆的功能基础。Burette et al (1999)的工作表明, 操作八臂迷宫空间延缓任务的 大鼠, 其海马-前额叶突触传递效能在延缓期 (30 $\min$ )受到持久抑制, 形成习得性 LTD, 说明 LTD 与 工作记忆相关。大鼠在操作空间工作记忆任务时, 其海马和前额叶的脑电图及局部场电位之间均存 在时相锁定(phase-locking)的同步化现象 (主要位于 theta 频段), 并且这种现象与空间工作记忆过程相 关(Jones \& Wilson, 2005a, b)。Siapas \& Wilson(1998) 发现, 大鼠海马和前额叶的脑电图在慢波睡眠时存 在时间相关, 由此可推测海马一前额叶回路可能参 与将白天所获信息在睡眠中进行巩固的过程。以上 的电生理证据表明, 海马一前额叶回路具有明显的 突触可塑性, 并提示该回路可能主要涉及长时记忆 巩固和工作记忆。

\section{3 海马一前额叶回路在工作记忆中的作用}

\section{1 海马、前额叶在工作记忆中的作用}

在灵长类和大鼠上已有很多证据表明海马和 前额叶在工作记忆中的作用不同。下面将按研究对 象分别加以介绍。

3.1.1 在灵长类上的研究结果 前额叶工作记忆 功能研究始自 20 世纪 30 年代耶鲁大学的 Jacobsen 等的先驱性工作。当时, Jacobsen 等将白眉猴和狒 狒的前额叶皮质切除, 采用直接延缓反应任务和交 互延缓任务测试其工作记忆功能 [当时他们称为“近 期记忆(recent memory)”或瞬时记忆 “(immediate memory)”], 首次发现双侧前额叶切除的猴的工作 记忆严重受损, 且延缓时间越长, 损伤越严重 (Jacobsen, 1935, 1936; Jacobsen \& Nissen, 1937)。 Goldman \& Rosvold(1970)在对恒河猴的损毁研究 上把空间工作记忆的关键脑区定位于背外侧前额 叶的主沟区 (principle sulcus area) 和弓状沟区 (arcuate sulcus area)。Bauer \& Fuster(1976)发现用冷 却抑制猴的背外侧前额叶的神经元的活动同样可 以造成工作记忆损伤, 进一步印证了 Jacobsen 等的 结果。Fuster \& Alexander(1971)以及 Kubota \&
Niki(1971)于同年分别报道在操作延缓反应任务或 交互延缓任务的猴的前额叶中记录到了延缓相关 的神经元单位放电活动(single unit activity)显著增 强的现象。这是前额叶参与工作记忆功能的最早的 电生理学证据; 但由于前面这两项研究中操作任务 的猴没有固定头部, 不能排除猴通过一直注视着暗 示位点方向来完成任务, 所以耶鲁大学 Goldman-Rakic 实验室采用眼动延缓反应任务 (oculomotor delayed-response task)最终排除了这个 可能, 从而给出了恒河猴背外侧前额叶参与工作记 忆的最坚实的电生理学证据(Funahashi et al, 1989)。

早在 1957 年, Scoville \& Milner 就已报道包括 海马在内的内侧题叶(medial temporal cortex)被切 除后不能再形成新的陈述性长时记忆的病例, 其中 最著名的 H.M. 患者在手术后对新的信息只能保持 很短的时间 (20 s 左右)。这提示海马受损患者的具 有一定的工作记忆能力, 但其所能记忆信息的时间 长度受限。Zola-Morgan \& Squire(1985)训练恒河猴 操作延缓时间为的 $8 、 15$ 和 $30 \mathrm{~s}$ 的延缓反应任务, 将内侧题叶 [主要包括海马和杏仁体(amygdala)在内] 切除后, $8 \mathrm{~s}$ 延缓的成绩与正常对照无差异, 但 $15 \mathrm{~s}$ 和 $30 \mathrm{~s}$ 延缓的成绩则显著下降, 说明海马对只需保 持较短时间 ( $\leqslant 10 \mathrm{~s}$ ) 的工作记忆任务来说并不是必 要的。Watanabe \& Niki(1985)首先在操作延缓反应 任务的日本猴的海马中记录到了延缓相关的神经 元单位放电现象。Cahusac et al (1989)在操作空间延 缓反应任务的猴的海马中也记录到延缓相关的神 经元发放活动。Goldman-Rakic 实验室采用 2-脱氧 葡萄糖同位素标记和放射自显影技术证明, 操作延 缓反应任务的恒河猴, 其背外侧前额叶和海马（主 要是 CA1 亚区、齿状回和下托) 的代谢活动均显著 增强, 这提示猴的海马和前额叶均在工作记忆中发 挥作用 (延缓反应任务: Friedman \& Goldman-Rakic, 1988, 1994; Goldman-Rakic \& Friedman 1991; 眼动 延缓反应任务: Sybirska et al, 2000)。Inoue et al (2004)采用正电子发射断层成像(positron emission tomography, PET)技术监视操作眼动延缓反应任务 的恒河猴的大脑血流(regional cerebral blood flow, $\mathrm{rCBF}$ )变化, 发现猴的前额叶各亚区的 $\mathrm{rCBF}$ 值与其 任务正确率呈正相关, 而海马的 $\mathrm{rCBF}$ 值与其正确 率呈负相关, 提示前额叶与海马均参与工作记忆, 但发挥的作用不同。以上的电生理和脑功能成像研 究结果也支持海马和前额叶在工作记忆中发挥作 
用。人们已经发现, 损伤人和猴的前额叶, 特别是 背外侧前额叶, 不论延缓时间长短, 其工作记忆均 显著受损; 而海马受损的猴或患者可以正常的完成 延缓时间较短的工作记忆任务, 但很难完成延缓时 间更长的任务(Goldman-Rakic, 1987; Zola-Morgan \& Squire, 1985)。以上结果表明, 灵长类前额叶是 工作记忆的关键脑区; 海马的功能可能是作为一个 信息缓冲器(buffer), 可以在更长的时间尺度上继续 保持信息。如果延缓时间在前额叶的保持限度 (如 在猴上是 $10 \mathrm{~s}$ 左右) 内, 前额叶本身可以保持信息, 故损毁海马不影响工作记忆, 但当延缓时间超过这 个限度, 前额叶自身不能再保持, 而需要海马参与 时, 海马损毁造成的效果就表现出来了。

Abrahams et al (1999)采用九箱迷宫(Nine-Box Maze) 任务测试癫㾁患者的工作记忆和参考记忆能 力并用磁共振(magnetic resonance imaging, MRI)技 术测量其海马体积, 其研究表明, 右侧题叶癫㾁患 者的空间工作记忆成绩显著低于左侧题叶癫㾁患 者和正常人, 右侧题叶癫㾁患者的右侧海马体积也 显著小于其左侧海马及左侧题叶癫㾁患者和正常 人的右侧海马, 表明空间工作记忆成绩与右侧海马 体积呈正相关, 提示右侧海马在工作记忆中可能更 重要。近年来脑功能成像技术的应用揭示了工作记 忆涉及的脑结构。PET 研究发现, 操作物体和空间 交互延缓任务的人右侧海马只在延缓期非常短时 (1 $-5 \mathrm{~s})$ 才会被激活, 提示海马可能以特殊的方式参与 工作记忆(Curtis et al, 2000)。接下来人们采用功能 性磁共振成像(functional MRI, fMRI)技术记录操作 复杂图片或面孔的视觉 N-back 任务 (一种常用于 人类被试的工作记忆任务) 的人的脑功能变化, 发 现海马主要在新异事物相关的工作记忆过程中被 激活, 而前额叶则主要在熟悉事物相关的工作记忆 中被激活(Ranganath \& D'Esposito, 2001; Ranganath et al, 2004; Stern et al, 2001; Zarahn et al, 2005)。以上 研究表明, 前额叶和海马在工作记忆中既有分工又 有合作, 两者相互协调, 共同完成各种工作记忆任 务。

3.1.2 在大鼠上的研究结果一项采用八臂迷宫 延缓任务, 药物损毁大鼠海马和前额叶的研究表 明, 当延缓时间很短时 $(10 \mathrm{~s})$, 大鼠的海马和前额叶 同等重要地参与空间信息处理, 损伤两者之一并不 出现工作记忆障碍; 而当延缓时间超出短时范畴时 (5 min), 前额叶受损对工作记忆无明显影响, 而损
伤海马则造成明显工作记忆障碍(Lee \& Kesner, 2003)。此项工作支持海马在空间信息处理中起更加 关键的作用。而最近的一项研究则表明, 抑制海马 和前额叶的功能都可造成工作记忆障碍, 但抑制海 马造成的损伤更严重, 并且还造成包括空间参考记 忆在内的多种记忆功能的损伤(Yoon et al, 2008)。从 以上研究可以看出, 海马和前额叶在空间工作记忆 中的作用具有时间相关性。在工作记忆中，啮齿类 的海马较前额叶更重要, 而灵长类的前额叶较海马 更关键。这表明海马和前额叶在学习和记忆中的作 用存在种属差异, 这可能与前额叶的系统进化特点 有关。已知, 啮齿类的前额叶刚出现, 进化程度较 差, 而灵长类特别是人类的前额叶的进化程度在所 有动物之上, 最发达(Fuster, 1997b)。可能在灵长类 动物的大脑演化过程中, 部分认知功能已经从海马 转移到了前额叶。

\section{2 海马一前额叶回路在工作记忆中的作用}

既然海马和前额叶均参与工作记忆, 那么它们 之间的回路在工作记忆过程中起什么作用呢? 一 项采用八臂迷宫延缓任务进行的研究表明, 以可逆 的方式阻断大鼠海马一前额叶回路, 其计划功能和 提取短时存储的空间信息的能力受损，但可顺利完 成延缓时间很短的工作记忆任务(Floresco et al, 1997), 前额叶多巴胺 D1 受体及胞内 cAMP-PKA 信号转导通路均被证明在其中起到重要调控作用 (Seamans et al, 1998; Aujla \& Beninger, 2001)。问题 是, 这些研究采用的可逆阻断的药物利多卡因 (lidocaine)是非选择性的, 不能排除过路纤维受损对 记忆功能造成的影响; 同时, 其采用的八臂迷宫作 业不能避免动物采用连续左转或右转 45 度角的非 记忆反应模式完成任务(Dubreuil et al, 2003)。因此, 有必要采用更具选择性的阻断方法和更有针对性 的工作记忆任务研究海马一前额叶回路在工作记忆 中的作用。我们采用了可以选择性抑制神经元胞体 的蝇蔁醇(muscimol)来阻断大鼠海马一前额叶回路, 以 $\mathrm{T}$-迷宫交互延缓任务进行测试, 发现海马一前额 叶回路被阻断后, 动物在该任务中的错误率显著上 升, 表明其工作记忆受到严重损伤; 进一步分析其 错误类型, 则发现其工作记忆类型的错误和坚持性 错误均显著升高, 说明海马一前额叶回路不仅参与 工作记忆，而且还参与抑制控制(Wang \& Cai, 2006)。这是继 Izaki et al (2001)和 Maruki et al (2001) 之后, 提出的前额叶和腹侧海马均参与工作记忆和 
抑制控制功能的又一实验证据。在此基础上, 我们 进一步证明, 海马一前额叶回路是工作记忆功能的 关键(Wang \& Cai, 2006)。以上研究结果表明, 工 作记忆是在多个相互联系的脑结构所构成的神经 回路或网络上形成的。这也正是 Fuster (1997a)提出 的“网络记忆(network memory)”理论所要阐述的观 点。

精神分裂症(schizophrenia)、帕金森氏综合征 (Parkinson's disease, PD)、阿尔兹海默氏症 (Alzheimer's disease, AD)等神经、精神疾病患者都 表现出工作记忆障碍和前额叶功能异常, 并发现其 与神经递质系统失调密切相关(Oscar-Berman et al, 1991)。近几年的研究也表明, 应激可持续损伤海马 一前额叶突触的可塑性, 应激导致的海马一前额叶回 路功能异常可能与创伤应激综合征(posttraumatic stress disorder, PTSD)、抑有症(depression)的发生相 关(Jay et al, 2004; Rocher et al, 2004)。全身应用致幺 剂苯环己哌啶(phencyclidine, PCP)可在自由活动的 大鼠上诱发精神分裂症样症状, 并可在前额叶中引 起强烈的神经元放电(Suzuki, 2002)。PCP 在前额叶 中引发的这种作用可通过向腹侧海马而非前额叶 内注射谷氨酸 NMDA 受体阻断剂 MK-801 消除, 表明 PCP 是通过海马一前额叶回路发挥作用的(Jodo et al, 2005)。这同时表明海马-前额叶回路与精神分 裂症的产生有关, 并提示 PCP 作为一种心理成瘾药 物是通过该回路发挥致幻作用的, 从而将海马一前 额叶回路功能与药物成瘾联系在一起。我们还发 现, 新生期温柔的触觉刺激可提高幼年经历短暂母 贞隔离的成年大鼠的工作记忆, 并增强海马传入纤
维与前额叶神经元间突触的可塑性, 提示海马一前 额叶回路在工作记忆等认知功能的发育过程中也 起重要作用(Zhang \& Cai, 2008)。而这些认知功能及 其相关的神经回路能否发育正常, 则可能是以上神 经精神疾病发生的关键。这些研究结果表明, 海马 - 前额叶回路可能参与多种认知功能, 并与多种神 经、精神疾病的发生存在关联。

\section{4 问题与展望}

工作记忆是行为计划、语言、思维和意识等高 级认知功能的基础(Baddeley, 2003)。人们现在已知, 海马-前额叶回路是工作记忆的关键神经回路, 但 工作记忆只是海马和前额叶共有的功能之一。海马 一前额叶回路还有哪些功能, 其调控机制如何。这 些问题有待进一步探索。现有的证据提示, 对包括 海马-前额叶回路在内的工作记忆神经回路及其神 经调控机制的深入了解有助于理解相关的神经、精 神疾病的发病机理, 并促进有效治疗手段的开发。 同时, 相关研究还会促进人们了解脑高级认知功能 的工作原理, 并将之用于人工智能的开发与应用。

国际著名神经科学家、美国科学院和医学科学 院院士、耶鲁大学教授 Patricia Shoer Goldman-Rakic(1937-2003 年)逝世到 2009 年为止 已 6 周年了。谨以此文纪念她在前额叶和工作记忆 的开拓性研究中及在精神分裂症和意识研究中做 出的卓越贡献。正是她的贡献, 使我们对前额叶的 结构、功能以及精神分裂症的发病机理有了深刻的 认识。

\section{参考文献:}

Abrahams S, Morris RG, Polkey CE, Jarosz JM, Cox TC, Graves M, Pickering A. 1999. Hippocampal involvement in spatial and working memory: a structural MRI analysis of patients with unilateral mesial temporal lobe sclerosis [J]. Brain Cogn, 41(1): 39-65.

Aujla H, Beninger RJ. 2001. Hippocampal-prefrontocortical circuits: PKA inhibition in the prefrontal cortex impairs delayed nonmatching in the radial maze in rats [J]. Behav Neurosci, 115(6): 1204-1211.

Baddeley A. 2003. Working memory: looking back and looking forward [J]. Nat Rev Neurosci, 4(10): 829-839.

Barbas H, Blatt GJ. 1995. Topographically specific hippocampal projections target functionally distinct prefrontal areas in the rhesus monkey [J]. Hippocampus, 5(6): 511-533.

Bauer RH, Fuster JM. 1976. Delayed-matching and delayed-response deficit from cooling dorsolateral prefrontal cortex in monkeys [J]. J Comp Physiol Psychol, 90(3): 293-302.
Burette F, Jay T, Laroche S. 1999. Synaptic depression of the hippocampal to prefrontal cortex pathway during a spatial working memory task $[\mathrm{J}]$. Curr Psychol Lett, 1(1): 9-23.

Burette F, Jay TM, Laroche S. 1997. Reversal of LTP in the hippocampal afferent fiber system to the prefrontal cortex in vivo with low-frequency patterns of stimulation that do not produce LTD [J]. $J$ Neurophysiol, 78(2): 1155-1160.

Cahusac PM, Miyashita Y, Rolls ET. 1989. Responses of hippocampal formation neurons in the monkey related to delayed spatial response and object-place memory tasks [J]. Behav Brain Res, 33(3): 229-240.

Cavada C, Compañy T, Tejedor J, Cruz-Rizzolo RJ, Reinoso-Suárez F. 2000. The Anatomical Connections of the Macaque Monkey Orbitofrontal Cortex. A Review [J]. Cereb Cortex, 10(3): 220-242.

Cavada C, Llamas A, Reinoso-Suárez F. 1983. Allocortical afferent connections of the prefrontal cortex in the cat [J]. Brain Res, 260(1): 
117-120.

Croxson PL, Johansen-Berg H, Behrens TE, Robson MD, Pinsk MA, Gross CG, Richter W, Richter MC, Kastner S, Rushworth MF. 2005. Quantitative investigation of connections of the prefrontal cortex in the human and macaque using probabilistic diffusion tractography $[\mathrm{J}] . \mathrm{J}$ Neurosci, 25(39): 8854-8866.

Curtis CE, Zald DH, Lee JT, Pardo JV. 2000. Object and spatial alternation tasks with minimal delays activate the right anterior hippocampus proper in humans [J]. Neuroreport, 11(10): 2203-2207.

Dégenètais E, Thierry AM, Glowinski J, Gioanni Y. 2003. Synaptic influence of hippocampus on pyramidal cells of the rat prefrontal cortex: an in vivo intracellular recording study [J]. Cereb Cortex, 13(7): 782-792.

Dubreuil D, Tixier C, Dutrieux G, Edeline JM. 2003. Does the radial arm maze necessarily test spatial memory? [J]. Neurobiol Learn Mem, 79(1): 109-117.

Floresco SB, Seamans JK, Phillips AG. 1997. Selective roles for hippocampal, prefrontal cortical, and ventral striatal circuits in radial-arm maze tasks with or without a delay [J]. J Neurosci, 17(5): 1880-1890.

Friedman HR, Goldman-Rakic PS. 1988. Activation of the hippocampus and dentate gyrus by working-memory: a 2-deoxyglucose study of behaving rhesus monkeys [J]. J Neurosci, 8(12): 4693-4706.

Friedman HR, Goldman-Rakic PS. 1994. Coactivation of prefrontal cortex and inferior parietal cortex in working memory tasks revealed by $2 \mathrm{DG}$ functional mapping in the rhesus monkey [J]. J Neurosci, 14(5 Pt 1): 2775-2788.

Funahashi S, Bruce CJ, Goldman-Rakic PS. 1989. Mnemonic coding of visual space in the monkey's dorsolateral prefrontal cortex $[\mathrm{J}] . J$ Neurophysiol, 61(2): 331-349.

Fuster JM. 1997a. Network memory [J]. Trends Neurosci, 20(10): 451-459.

Fuster JM. 1997b. The Prefrontal Cortex: Anatomy, Physiology, and Neuropsychology of the Frontal Lobe $[\mathrm{M}]$. New York: Lippincott-Raven.

Fuster JM, Alexander GE. 1971. Neuron activity related to short-term memory [J]. Science, 173(3997): 652-654.

Gabbott P, Headlam A, Busby S. 2002. Morphological evidence that CA1 hippocampal afferents monosynaptically innervate PV-containing neurons and NADPH-diaphorase reactive cells in the medial prefrontal cortex (Areas 25/32) of the rat [J]. Brain Res, 946(2): 314-322.

Goldman PS, Rosvold HE. 1970. Localization of function within the dorsolateral prefrontal cortex of the rhesus monkey [J]. Exp Neurol, 27(2): 291-304.

Goldman-Rakic PS. 1987. Circuitry of the Primate Prefrontal Cortex and Regulation of Behavior by Representational Memory[M]// Mountcastle PF. Handbook of Physiology: the Nervous System: Vol. 5 Higher Functions of the Brain, Part 1. Bethesda, MD: American Physiological Association, 373-417.

Goldman-Rakic PS, Friedman HR. 1991. The Circuitry of Working Memory Revealed by Anatomy and Metabolic Imaging $[\mathrm{M}] / /$ Levin HS, Eisenberg HM, Benton AL. Frontal Lobe Function and Dysfunction. Oxford: Oxford University Press, 73-91.

Goldman-Rakic PS, Selemon LD, Schwartz ML. 1984. Dual pathways connecting the dorsolateral prefrontal cortex with the hippocampal formation and parahippocampal cortex in the rhesus monkey [J]. Neuroscience, 12(3): 719-743.

Hurley KM, Herbert H, Moga MM, Saper CB. 1991. Efferent projections of the infralimbic cortex of the rat [J]. J Comp Neurol, 308(2): 249-276.

Inoue M, Mikami A, Ando I, Tsukada H. 2004. Functional brain mapping of the macaque related to spatial working memory as revealed by PET [J]. Cereb Cortex, 14(1): 106-119.
Irle E, Markowitsch HJ. 1982. Widespread cortical projections of the hippocampal formation in the cat [J]. Neuroscience, 7(11): 2637-2647.

Izaki Y, Maruki K, Hori K, Nomura M. 2001. Effects of rat medial prefrontal cortex temporal inactivation on a delayed alternation task $[\mathrm{J}]$. Neurosci Lett, 315(3): 129-132.

Izaki Y, Takita M, Akema T. 2003. Compatibility of bidirectional synaptic plasticity on hippocampo-prefrontal cortex pathway in rats [J]. Neurosci Lett, 345(1): 69-71.

Jacobsen CF. 1936. Studies of cerebral function in primates: I. The function of the frontal association areas in monkeys [J]. Comp Psychol Monogr, 13: 3-60.

Jacobsen CF. 1935. Functions of frontal association area in primates [J]. Arch Neurol Psychiatry, 33(3): 558-569.

Jacobsen CF, Nissen HW. 1937. Studies of cerebral function in primates: IV. The effect of frontal lobe lesions on the delayed alternation habit in monkeys [J]. J Comp Psychol, 23(1): 101-112.

Jay TM, Burette F, Laroche S. 1995. NMDA receptor-dependent long-term potentiation in the hippocampal afferent fibre system to the prefrontal cortex in the rat [J]. Eur J Neurosci, 7(2): 247-250.

Jay TM, Burette F, Laroche S. 1996. Plasticity of the hippocampal-prefrontal cortex synapses [J]. J Physiol Paris, 90(5-6): 361-366.

Jay TM, Glowinski J, Thierry AM. 1989. Selectivity of the hippocampal projection to the prelimbic area of the prefrontal cortex in the rat $[\mathrm{J}]$. Brain Res, 505(2): 337-340.

Jay TM, Rocher C, Hotte M, Naudon L, Gurden H, Spedding M. 2004. Plasticity at hippocampal to prefrontal cortex synapses is impaired by loss of dopamine and stress: importance for psychiatric diseases $[\mathrm{J}]$. Neurotox Res, 6(3): 233-244.

Jodo E, Suzuki Y, Katayama T, Hoshino KY, Takeuchi S, Niwa SI, Kayama Y. 2005. Activation of medial prefrontal cortex by phencyclidine is mediated via a hippocampo-prefrontal pathway [J]. Cereb Cortex, 15(5): 663-669.

Jones MW, Wilson MA. 2005a. Phase precession of medial prefrontal cortical activity relative to the hippocampal theta rhythm $[\mathrm{J}]$. Hippocampus, 15(7): 867-873.

Jones MW, Wilson MA. 2005b. Theta rhythms coordinate hippocampal-prefrontal interactions in a spatial memory task [J]. PLoS Biol, 3(12): e402.

Kubota K, Niki H. 1971. Prefrontal cortical unit activity and delayed alternation performance in monkeys $[\mathrm{J}]$. $J$ Neurophysiol, 34(3): 337-347.

Laroche S, Davis S, Jay TM. 2000. Plasticity at hippocampal to prefrontal cortex synapses: dual roles in working memory and consolidation $[\mathrm{J}]$ Hippocampus, 10(4): 438-446.

Laroche S, Jay TM, Thierry AM. 1990. Long-term potentiation in the prefrontal cortex following stimulation of the hippocampal CA1/subicular region [J]. Neurosci Lett, 114(2): 184-190.

Lee I, Kesner RP. 2003. Time-dependent relationship between the dorsal hippocampus and the prefrontal cortex in spatial memory $[\mathrm{J}] . J$ Neurosci, 23(4): 1517-1523.

Leichnetz GR, Astruc J. 1975. Preliminary evidence for a direct projection of the prefrontal cortex to the hippocampus in the squirrel monkey [J]. Brain Behav Evol, 11(5-6): 355-364.

Maruki K, Izaki Y, Hori K, Nomura M, Yamauchi T. 2001. Effects of rat ventral and dorsal hippocampus temporal inactivation on delayed alternation task [J]. Brain Res, 895(1-2): 273-276.

Olton DS, Becker JT, Handelman GE. 1979. Hippocampus, space and memory. [J]. Behav Brain Sci, 2: 313-322.

Oscar-Berman M, McNamara P, Freedman M. 1991. Delayed-reponseTasks: Parallels Between Experimental Ablation Studies and Findings in 
Patients with Frontal Lesions $[\mathrm{M}] / /$ Levin HS, Eisenberg HM, Benton AL. Frontal Lobe Fuction and Dysfuction. Oxford: Oxford University Press, 231-255.

Parent MA, Wang L, Su JJ, Netoff T, Yuan LL. 2010. Identification of the hippocampal input to medial prefrontal cortex in vitro [J]. Cereb Cortex, 20(2):393-403

Rakic P. 2007. Forward to the special issue on the prefrontal cortex and working memory: in memory of Patricia S. Goldman-Rakic [J]. Cereb Cortex, 17 Suppl 1: i1-i3.

Ranganath C, Cohen MX, Dam C, D'Esposito M. 2004. Inferior temporal, prefrontal, and hippocampal contributions to visual working memory maintenance and associative memory retrieval [J]. J Neurosci, 24(16): 3917-3925.

Ranganath C, D'Esposito M. 2001. Medial temporal lobe activity associated with active maintenance of novel information [J]. Neuron, 31(5): 865-873.

Rocher C, Spedding M, Munoz C, Jay TM. 2004. Acute stress-induced changes in hippocampal/prefrontal circuits in rats: effects of antidepressants [J]. Cereb Cortex, 14(2): 224-229.

Rosene DL, Van Hoesen GW. 1977. Hippocampal efferents reach widespread areas of cerebral cortex and amygdala in the rhesus monkey [J]. Science, 198(4314): 315-317.

Scoville WB, Milner B. 1957. Loss of recent memory after bilateral hippocampal lesions [J]. J Neurol Neurosurg Psychiatry, 20(1): 11-21.

Seamans JK, Floresco SB, Phillips AG. 1998. D1 receptor modulation of hippocampal-prefrontal cortical circuits integrating spatial memory with executive functions in the rat [J]. J Neurosci, 18(4): 1613-1621.

Sesack SR, Deutch AY, Roth RH, Bunney BS. 1989. Topographical organization of the efferent projections of the medial prefrontal cortex in the rat: an anterograde tract-tracing study with Phaseolus vulgaris leucoagglutinin [J]. J Comp Neurol, 290(2): 213-242.

Siapas AG, Wilson MA. 1998. Coordinated interactions between hippocampal ripples and cortical spindles during slow-wave sleep [J]. Neuron, 21(5): 1123-1128.

Stern CE, Sherman SJ, Kirchhoff BA, Hasselmo ME. 2001. Medial temporal and prefrontal contributions to working memory tasks with novel and familiar stimuli [J]. Hippocampus, 11(4): 337-346.

Suzuki Y, Jodo E, Takeuchi S, Niwa S, Kayama Y. 2002. Acute administration of phencyclidine induces tonic activation of medial prefrontal cortex neurons in freely moving rats [J]. Neuroscience, 114(3): 769-779.
Sybirska E, Davachi L, Goldman-Rakic PS. 2000. Prominence of direct entorhinal-CA1 pathway activation in sensorimotor and cognitive tasks revealed by 2 -DG functional mapping in nonhuman primate [J]. $J$ Neurosci, 20(15): 5827-5834

Takita M, Izaki Y, Jay TM, Kaneko H, Suzuki SS. 1999. Induction of stable long-term depression in vivo in the hippocampal-prefrontal cortex pathway [J]. Eur J Neurosci, 11(11): 4145-4148.

Thierry AM, Gioanni Y, Degenetais E, Glowinski J. 2000. Hippocampo-prefrontal cortex pathway: anatomical and electrophysiological characteristics [J]. Hippocampus, 10(4): 411-419.

Vertes RP. 2002. Analysis of projections from the medial prefrontal cortex to the thalamus in the rat, with emphasis on nucleus reuniens [J]. J Comp Neurol, 442(2): 163-187.

Vertes RP, Hoover WB, Szigeti-Buck K, Leranth C. 2007. Nucleus reuniens of the midline thalamus: Link between the medial prefrontal cortex and the hippocampus [J]. Brain Res Bull, 71(6): 601-609.

Verwer RW, Meijer RJ, Van Uum HF, Witter MP. 1997. Collateral projections from the rat hippocampal formation to the lateral and medial prefrontal cortex [J]. Hippocampus, 7(4): 397-402.

Wang GW, Cai JX. 2006. Disconnection of the hippocampal-prefrontal cortical circuits impairs spatial working memory performance in rats [J]. Behav Brain Res, 175(2): 329-336.

Watanabe T, Niki H. 1985. Hippocampal unit activity and delayed response in the monkey [J]. Brain Res, 325(1-2): 241-254.

$\mathrm{Xu}$ L, Cai JX. 2009. Ethological research methods [M]// Han JS. Neuroscience. Beijing: Peking University Medical Press, 118-135. [徐 林, 蔡景霞. 2009. 行为学研究方法 $[\mathrm{M}] / /$ 韩济生. 神经科学. 北京: 北京大学医学出版社, 118-135.]

Yoon T, Okada J, Jung MW, Kim JJ. 2008. Prefrontal cortex and hippocampus subserve different components of working memory in rats [J]. Learn Mem, 15(3): 97-105.

Zarahn E, Rakitin B, Abela D, Flynn J, Stern Y. 2005. Positive evidence against human hippocampal involvement in working memory maintenance of familiar stimuli [J]. Cereb Cortex, 15(3): 303-316.

Zhang M, Cai JX. 2008. Neonatal tactile stimulation enhances spatial working memory, prefrontal long-term potentiation, and D1 receptor activation in adult rats [J]. Neurobiol Learn Mem, 89(4): 397-406.

Zola-Morgan S, Squire LR. 1985. Medial temporal lesions in monkeys impair memory on a variety of tasks sensitive to human amnesia $[\mathrm{J}]$ Behav Neurosci, 99(1): 22-34. 